Eastern Dispensary in Whitechapel ; and as he passed through London to take up his duties he saw the crowd witnessing the execution of Müller for the murder of Mr. Briggs in 1864 . For the pain, squalor and vice of Whitechapel, M'Kendrick exchanged the purity and serenity of Glen Nevis, for he became surgeon to the Belford Cottage Hospital at Fort William in 1865. It was in Lochaber that he met Hughes Bennett accidentally, and soon became his assistant. From 1870 until I873, when Bennett's ill-health compelled him to winter abroad, M'Kendrick had sole charge of the university classes at Edinburgh, which he conducted with marked success. Bennett resigned in 1873 , and Rutherford was recalled from King's College, London, to fill the vacant chair, so that $\mathrm{M}^{\prime}$ Kendrick applied for and obtained the lectureship in physiology at Surgeons' Hall, and that at the Dick Veterinary College, Edinburgh. Here it was that he met James Dewar, with whom was begun that joint research which resulted in the discovery of the electric current produced in the retina and optic nerve when a beam of light was allowed to enter the eye.

For the first time in the history of physiology a current of action had been demonstrated in a sensory nerve by the normal stimulation of its end-organ. That Holmgren in Upsala made the same discovery about the same time was, of course, unknown to the Scottish workers. Dewar and $\mathrm{M} \cdot$ Kendrick also investigated the physiological action of chinoline and the pyridenes, becoming once more pioneers, this time in researches into the correlation between chemical structure and physiological effect. In $1872 \mathrm{M}^{\top}$ Kendrick visited Germany, and met Schultze, Pflüger, Du BoisRaymond, Ludwig and Helmholtz. His "Life of Helmholtz" is perhaps his best piece of writing; it is an admirable account of a life with little incident in it apart from the scientific discoveries.

In $1876 \mathrm{M}^{\circ}$ Kendrick was appointed to the chair of the Institutes of Medicine at the University of Glasgow ; and here a Department of Physiology was created out of a lecture-room, a sphygmograph, a few microscopes and some diagrams.

M'Kendrick was one of the most agreeable scientific lecturers Scotland has produced : his discourse had all the charm of a tale pleasantly told. In $x 87 \mathrm{x}$ he had been elected a fellow of the Royal College of Physicians of Edinburgh. In I $88 \mathrm{r}$ he was appointed Fullerian professor of physiology at the Royal Institution, in which capacity he delivered many Friday evening discourses, as well as Christmas lectures to the children, and a valuable series on the history of physiology. In I 882 he received the degree of LL.D. from his Alma Mater ; and two years later was elected into the Royal Society on the Council of which he afterwards served. He had been president of the Royal Society of Edinburgh, of the Section of Physiology of the British Association, of the Glasgow Philosophical Society; and he acted as examiner in a large number of universities. He delivered two courses of Thomson lectures at the Free Church College at Aberdeen.

$M^{\prime}$ Kendrick wrote with ease; he was the author of the articles on ear, eye, senses, stereoscope, longevity, and nervous system in the "Encyclopædia Britannica," as well as of "The Outlines of Physiology" published in 1878 , and ten years later of a "Text-book" in two volumes splendidly illustrated. In conjunction with his assistant, Dr. Snodgrass, he wrote an interesting volume on "The Physiology of the Senses."

From I892 onwards M'Kendrick, who had always been interested in physiological acoustics, investigated the tracing on the surface of the wax cylinder of the phonograph by a photographic method. Later he devised an apparatus to eliminate the hissing sounds which mar the music reproduced by that instrument. $\mathrm{M}^{\circ}$ Kendrick was very fond of music, of poetry and of animals. He published a volume of devotional verse. His disposition was that of a deeply religious and reverent man who, though enjoying fun, disliked frivolity. His sympathies were wide, his friendships many, his capacity for bringing the best out of every one conspicuous. He urged moderation in the use of strong drink ; some of his best addresses are those dealing with this subject.

$\mathrm{M}^{\prime}$ Kendrick married in 1867 a daughter of W. Souttar of Aberdeen, who died in 1898 . He is survived by two sons-Dr. J. S. M'Kendrick of Glasgow, and Colonel Anderson M'Kendrick, I.M.S. (retired), director of the Laboratory of the Royal Colleges at Edinburgh-and by one daughter.

\section{Fraser Harris.}

\section{WE regret to announce the following deaths:}

Prof. E. G. Browne, Sir Thomas Adams professor of Arabic in the University of Cambridge and fellow and president of Pembroke College, known for his work on Persian literature and on the history and literature of oriental religions, on January 5, aged sixty-three years.

Dr. R. Caton, C.B.E., pro-chancellor and emeritus professor of physiology in the University of Liverpool, and vice-chairman of the Liverpool School of Tropical Medicine, on January 2.

Rev. George Henslow, lately professor of botany to the Royal Horticultural Society, and from 1882 until r904 president of the Ealing Natural History Society, on December 30 , aged ninety years.

Prof. Martin Kirchner, who was prominently associated with the anti-tuberculosis campaign and with the framing of the German laws relating to infectious diseases, on November II, aged seventyone years,

Mr. Frank Morey, honorary curator of the Prince Henry of Battenburg Memorial Museum at Carisbrooke Castle, Isle of Wight, and editor and joint author of "The Guide to the Natural History of the Isle of Wight," on December 29, aged sixty-seven years.

Dr. James Murie, formerly assistant-secretary and librarian of the Linnean Society, and naturalist to Consul Petherick's expedition of $186 \mathrm{r}$ to Gondokoro, on December 2I, aged ninety-five years.

Erratum.-Mr. Edgar R. Waite, the Director of the South Australian Museum, Adelaide, informs us that the details given in the obituary announcement referring to Mr. A. R. McCulloch, which appeared in NATURE of October 24, 1925, p. 620, are incorrect. Mr. McCulloch was zoologist at the Australian Museum, Sydney, where he devoted himself to research on fishes and crustaceans, and his death occurred on August 3I, at the age of about thirty-eight years.

$$
\text { NO. 2933, vOL. II 7] }
$$

